\title{
Stress and Sleeping Difficulties among First Year Medical Students
}

\author{
Authors \\ Deepa.G' ${ }^{1}$ Rupa.G ${ }^{2}$ \\ ${ }^{1,2}$ Assistant professor of Physiology, Govt. Medical College, Thiruvananthapuram \\ Corresponding Author \\ Deepa G \\ Dept. of Physiology, Govt. Medical College, Thiruvananthapuram, PIN 695011 \\ Email:deepamch@gmail.com, Mobile No: 9447090258
}

\begin{abstract}
Background: In recent years, there has been a growing incidence of the issues of stresses involved in medical education that can seriously affect their learning and academic performance. They may cut short their leisure activities and hours of sleep in order to achieve their goals. A cross-sectional, questionnaire-based study was carried out among the first year undergraduate medical students of Government Medical College, Thiruvananthapuram. Majority of students had perceived stress (68.4\%). Stress was not found to differ significantly on the basis of sex, age, place of residence and stay at hostel. Significant association was there between stress and poor family income and sleep disturbances (76\%).
\end{abstract}

Keywords: perceived stress, stress score, medical students, sleep quality, conventional teaching.

\section{Introduction}

Medicine is one of the most stressful fields of education because it demands high levels of academic and professional skills. Extensive work load combined with lack of leisure time, limited contacts with family and friends, less family income, high parental expectations and worry about future may contribute to medical student's stress ${ }^{[1,2,3,4]}$.

Students may cut short their time for leisure activities and sleep in order to achieve their goals. Stress during medical training is increasingly being reported in published literature from various developing countries like India, Thailand, Malaysia and Pakistan ${ }^{[5,6,7,8,9]}$.

Sleep is a physiological process for human beings, essential to life. Good quality as well as amount of sleep are essential for the students to have better cognitive performance and avoid physical and mental health problems. The quantitative component of sleep includes the duration while the qualitative component is a subjective measure of depth and feeling of restfulness upon awakening ${ }^{[10]}$. Medical students are considered as a population that is very much vulnerable to sleep related problems ${ }^{[6]}$. Most of the medical schools in India follow the conventional method of didactic teacher-centred techniques during the first year of MBBS like long lectures, tutorials, non-problem based learning and practical classes. Students have to face frequent exams - theory, practical and viva, throughout first year, for which they are given internal assessment marks. A pass grade has to be scored by the student to qualify for the next academic year. This adds the stress and disturbs the sleep of the student. 
In this medical college, there are students from different districts of Kerala as well as from other states of India, who belong to different cultural, socioeconomic and educational backgrounds. The present study is to find out the level of stress, quality of sleep as well as the association between level of stress and sleep among first year MBBS students who got admission during 2014 in this medical college.

\section{Materials and Methods \\ Study Design}

This was a cross sectional study done in all students (200) of first MBBS course, who got admission during the year 2014. The Institutional Ethical Committee and Research Committee approved this study. All students who were present during 3 consecutive sessions while taking the questionnaire were included and those who were unwilling or absent during these sessions were excluded. We got 196 completed questionnaires. In order to avoid bias, the data were collected after their University theory and practical examinations (as the study population included was 'vulnerable group). Written informed consent was obtained from all the participants. They were informed regarding the aim of this study and anonymity was assured.

\section{Questionnaire}

It had 4 sections.

1. Socio demographic data - Age, sex, family residence, place of accommodation and family income.

2. A 10-item Cohen Perceived stress scale (PSS-10 score) ${ }^{[12]}$.

PSS-10 score is a valid, reliable and widely used psychological tool that measures a person's perception of stress during the previous one month. 10 question version of PSS-10 was used. Students gave their ratings according to their emotional and cognitive responses to certain specific circumstances that occur in their day to day life, on a 5-point Likert scale ranging from $0-4$. [0=never, 1=almost never, 2=sometimes, $3=$ fairly often, 4=very often]. Positively worded items were reverse scored and total ratings taken. High scores indicate more perceived stress. According to this, PSS score $<13$ is low stress, 13 to 19 is average or moderate stress and $\geq 20$ is high stress.

3 . The Pittsburgh sleep quality index (PSQI) ${ }^{[10]}$ PSQI is a self-rating questionnaire that helps to assess the quality of sleep and disturbances during the previous one month. It consists of 19 individual items with an average score ranging from 0-21. PSQI score of 0 means good quality sleep. 1-10 is average sleep quality and $\geq 11$ is poor sleep quality. results AND data analysis

Quantitative variables were expressed in mean and standard deviation. Qualitative variables were expressed in proportion. Association between stress and sleep was assessed by Chi squared test. 'p' value of 0.05 was taken as the level of significance. The data was analysed using SPSS version 16.

Socio-demographic characteristics (Table 1)

Out of 200 students, 196 completed and returned the questionnaire (response rate of $98 \%$ ). The mean age was $19.4(\mathrm{SD}=0.9) .105$ students were males $(53.65 \%)$ and 91 were females (46.4\%). 133 were from urban area $(67.9 \%)$ and 63 from rural area $(32.1 \%) .141$ students $(71.9 \%)$ were residing in hostels and $55(28.1 \%)$ were day-scholars. 180 students $(91.8 \%)$ had satisfactory family income while $16(8.2 \%)$ had unsatisfactory family income.

Table -1: Socio demographic data

\begin{tabular}{|c|c|c|c|}
\hline \multirow[t]{2}{*}{ Data } & & & \\
\hline & & $\begin{array}{c}\text { Frequen } \\
\text { cy }\end{array}$ & $\begin{array}{c}\text { Percentag } \\
\mathrm{e}\end{array}$ \\
\hline \multirow[t]{2}{*}{ Age } & $<20$ & 190 & 96.9 \\
\hline & $>20$ & 6 & 3.1 \\
\hline \multirow[t]{2}{*}{ Gender } & Male & 105 & 53.6 \\
\hline & Female & 91 & 46.4 \\
\hline \multirow[t]{2}{*}{ Residence } & Urban & 133 & 67.9 \\
\hline & Rural & 63 & 32.1 \\
\hline \multirow{2}{*}{$\begin{array}{l}\text { Accommodatio } \\
\mathrm{n}\end{array}$} & With family & 55 & 28.1 \\
\hline & $\begin{array}{c}\text { Away from } \\
\text { family }\end{array}$ & 141 & 71.9 \\
\hline \multirow[t]{2}{*}{ Income } & Satisfactory & 180 & 91.8 \\
\hline & unsatisfactory & 16 & 8.2 \\
\hline
\end{tabular}




\section{JMSCR Vol||05||Issue||03||Page 18432-18436||March}

\section{Perceived stress}

Mean perceived stress score in the present study population was $22.7 \% \quad(\mathrm{SD}=6.3)$ (Table 2). 134 students had high stress $(68.4 \%)$ and 49 had moderate stress $(25 \%)$.

Table 2: Prevalence of stress

\begin{tabular}{|l|c|c|}
\hline Stress & Frequency & Percentage \\
\hline No stress & 13 & 6.6 \\
\hline Average & 49 & 25.0 \\
\hline High stress & 134 & 68.4 \\
\hline Total & 196 & 100.0 \\
\hline Mean (SD) & \multicolumn{2}{|c|}{$22.7(6.3)$} \\
\hline
\end{tabular}

There was no significant association between stress and age (Table-3). 96.8\% of average stress/no stress and $97 \%$ of high stress group were $<20$ years of age $(\mathrm{p}=0.928)$. No significant association was found between stress and gender. 58\% of average stress/no stress group and $51.5 \%$ of high stress group were males $(\mathrm{p}=0.391) .77 .4 \%$ of average stress/no stress group were residing in urban area where as $63.4 \%$ of high stress group were from rural area. There was a borderline significant difference observed in stress level between urban and rural population $(\mathrm{p}=0.051)$. No significant association was found between place of accommodation and stress $(p=0.791) .11 .2 \%$ of high stress group had unsatisfactory family income whereas only $1.6 \%$ of average stress/no stress group had unsatisfactory family income $(\mathrm{p}=0.023)$. This showed that family income had a significant association with the prevalence of stress.

Table-3: Factors associated with stress-Univariable analysis

\begin{tabular}{|c|c|c|c|c|c|c|c|c|c|c|}
\hline & \multicolumn{6}{|c|}{ Stress } & \multirow{3}{*}{$\chi^{2}$} & \multirow{3}{*}{$\mathrm{df}$} & \multirow{3}{*}{$\mathrm{p}$} \\
\hline & & \multicolumn{2}{|c|}{$\begin{array}{l}\text { Average stress / } \\
\text { no stress }(\mathrm{N}=62)\end{array}$} & \multicolumn{2}{|c|}{$\begin{array}{l}\text { High stress } \\
(\mathrm{N}=134)\end{array}$} & \multicolumn{2}{|c|}{$\begin{array}{c}\text { Total } \\
(\mathrm{N}+196)\end{array}$} & & & \\
\hline & & $\mathrm{N}$ & $\%$ & $\mathrm{~N}$ & $\%$ & $\mathrm{~N}$ & $\%$ & & & \\
\hline Age & $\begin{array}{l}<20 \\
>20\end{array}$ & $\begin{array}{c}60 \\
2\end{array}$ & $\begin{array}{c}96.8 \\
3.2\end{array}$ & $\begin{array}{c}130 \\
4\end{array}$ & $\begin{array}{c}97.0 \\
3\end{array}$ & $\begin{array}{c}190 \\
6\end{array}$ & $\begin{array}{c}96.9 \\
3.1\end{array}$ & 0.008 & 1 & 0.928 \\
\hline Gender & $\begin{array}{c}\text { Male } \\
\text { Female }\end{array}$ & $\begin{array}{l}36 \\
26\end{array}$ & $\begin{array}{l}58.1 \\
41.9\end{array}$ & $\begin{array}{l}69 \\
65\end{array}$ & $\begin{array}{l}51.5 \\
46.6\end{array}$ & $\begin{array}{c}105 \\
91\end{array}$ & $\begin{array}{l}53.6 \\
46.4\end{array}$ & 0.736 & 1 & 0.391 \\
\hline $\begin{array}{l}\text { Place of } \\
\text { residence }\end{array}$ & $\begin{array}{l}\text { Urban } \\
\text { Rural }\end{array}$ & $\begin{array}{l}48 \\
14\end{array}$ & $\begin{array}{l}77.4 \\
22.6\end{array}$ & $\begin{array}{l}85 \\
49\end{array}$ & $\begin{array}{l}67.9 \\
32.1\end{array}$ & $\begin{array}{c}133 \\
63\end{array}$ & $\begin{array}{l}67.9 \\
32.1\end{array}$ & 3.802 & 1 & 0.051 \\
\hline $\begin{array}{l}\text { Accommo } \\
\text { dation }\end{array}$ & $\begin{array}{l}\text { With family } \\
\text { Away from } \\
\text { family }\end{array}$ & $\begin{array}{l}20 \\
42\end{array}$ & $\begin{array}{l}32.3 \\
67.7\end{array}$ & $\begin{array}{l}35 \\
99\end{array}$ & $\begin{array}{l}67.9 \\
32.1\end{array}$ & $\begin{array}{r}55 \\
141\end{array}$ & $\begin{array}{l}67.9 \\
32.1\end{array}$ & 0.791 & 1 & 0.374 \\
\hline Income & $\begin{array}{c}\text { Satisfactory } \\
\text { Unsatisfactory }\end{array}$ & $\begin{array}{l}61 \\
1\end{array}$ & $\begin{array}{r}98.4 \\
1.6\end{array}$ & $\begin{array}{l}119 \\
15\end{array}$ & $\begin{array}{l}91.8 \\
8.2\end{array}$ & $\begin{array}{c}180 \\
16\end{array}$ & $\begin{array}{l}91.8 \\
8.2\end{array}$ & 5.190 & 1 & .023 \\
\hline $\begin{array}{l}\text { Sleeping } \\
\text { habits }\end{array}$ & $\begin{array}{c}\text { Average } \\
\text { sleep } \\
\text { Poor sleep }\end{array}$ & $\begin{array}{l}31 \\
31\end{array}$ & $\begin{array}{l}50.0 \\
50.0\end{array}$ & $\begin{array}{c}16 \\
118\end{array}$ & $\begin{array}{l}24.0 \\
76.0\end{array}$ & $\begin{array}{l}47 \\
149\end{array}$ & $\begin{array}{l}24.0 \\
76.0\end{array}$ & 33.682 & 1 & 0.000 \\
\hline
\end{tabular}

\section{Quality of sleep}

Mean PSQI score in our study population was 13 $(\mathrm{SD}=4.6 \%)$. From Table-4, it was found that 149 students had poor sleep habit $(76.0 \%)$ for past one month and 47 had average sleep $(24.0 \%)$. The Chi squared test revealed a highly significant association between stress and poor quality of sleep (Chi squared test $=33.682 ; \mathrm{p}=0.000)$. The prevalence of poor quality of sleep among high stress population was $88.1 \%$. 
Table -4: Quality of sleep

\begin{tabular}{|l|c|c|}
\hline Sleep Habits & Frequency & Percentage \\
\hline Average sleep & 47 & 24.0 \\
\hline Poor sleep & 149 & 76.0 \\
\hline Total & 196 & 100.0 \\
\hline
\end{tabular}

Binary logistic regression analysis (Table 5)

Binary logistic regression model reveals that sleep habits was a significant predictor of stress $(\mathrm{p}=0.000)$. The adjusted Odds ratio for sleep habits was 6.394 with $95 \%$ confidence intervals 3.076 to 13.292 . Those having poor sleep habits had 6.394 times more chance to get severe stress than others.

Table 5: Binary Logistic regression model for stress Variables in the Equation.

\begin{tabular}{|c|c|c|c|c|c|c|c|c|}
\hline & \multirow[t]{2}{*}{$\mathrm{B}$} & \multirow[t]{2}{*}{ S.E. } & \multirow[t]{2}{*}{ Wald } & \multirow[t]{2}{*}{ df } & \multirow[t]{2}{*}{$\mathrm{p}$} & \multirow[t]{2}{*}{ OR } & \multicolumn{2}{|c|}{ 95\% C.I.for OR } \\
\hline & & & & & & & Lower & Upper \\
\hline SleepHabits & 1.855 & 0.373 & 24.692 & 1 & 0.000 & 6.394 & 3.076 & 13.292 \\
\hline Residence & 0.363 & 0.387 & 0.879 & 1 & 0.349 & 1.437 & 0.673 & 3.067 \\
\hline Income & 1.374 & 1.059 & 1.681 & 1 & 0.195 & 3.950 & 0.495 & 31.497 \\
\hline Constant & -6.181 & 1.436 & 18.532 & 1 & 0.000 & 0.002 & & \\
\hline
\end{tabular}

a.Variable(s) entered on step 1: Sleep Habits, Residence, Income.

\section{DISCUSSION}

The sample population in the present study were exposed to mostly teacher-centred, conventional teaching methods during I MBBS, where mainly theoretical aspects were taught. Present study reveals a high prevalence of psychological stress $(68.4 \%)$ and poor sleep quality $(76 \%)$. This is in accordance with previous studies ${ }^{[5,13,14]}$. Increased stress may be due to the extensive teaching curriculum in the first year which has to be covered in a limited time and high academic demands particularly during exam periods.

An interesting finding observed in the present study was that both males and females were equally affected by stress and sleep disturbances. Study report by Cohen et al ${ }^{[12]}$ also showed that there was no significant association between stress levels and gender in a sample of college students.

Another distinct finding in present study was that $88.11 \%$ of high stressed students were having poor quality of sleep, less than $5 \mathrm{hrs}$ per day. Insufficient sleep can lead to difficulties in interpersonal relationships, memory problems, depression, anxiety, alcoholism and drug abuse among students ${ }^{[5,11,15]}$. These results are consistent with previous studies conducted by Sreeramareddy et al ${ }^{[2]}$ and Shah et al[9], which reported a strong association between academic stressors and psychological morbidity among medical students, who were exposed to conventional teaching methods.

These results emphasize the importance of cherishing a positive learning environment for medical students.

\section{CONCLUSION}

The present study shows a high prevalence of perceived stress among first year medical students along with poor quality of sleep. These findings may affect their behaviour, learning ability and ultimately patient care. However, stress associated with a conventional teaching environment can be markedly reduced by introducing problem based learning curriculum from first year itself. Adequate changes must be adopted to improve the living conditions of medical students like stress management techniques and teaching strategies by faculties. Proper emotional support should also be given to the stressed students.

\section{REFERENCES}

1. Aguair SM, Vierira APGI, VIERA KMF, Mabrega JO. Burnout syndrome and associated factors among medical students: a cross sectional study. JBrasPsiquiatr. 2009; 58 (1): 34-8. 
2. Sreeramareddy CT, Shankar PR, Binu VS, Mukhopadhyay C, Ray B, Menezes RG. Psychological morbidity, sources of stress and coping strategies among undergraduate medical students of Nepal. BMC Med Educ. 2007; 7-26

3. Supe AN. A stydy of stress in medical students at Seth G.S medical college. J Postgrad Med. 1998, 44: 1-6.

4. Shapiro SL, Shapiro DE, Shwartz GE. Stress management in medical education: a review of the literature. Academic Medicine. 200; 75(7): 748-759.

5. Veldi M, Aluoja A, Vasar V. sleep quality and more common sleep- related problems in medical students. Sleep Med. 2005; 6: 269-75.

6. Sathidevi VK. Development of Medical Students Stressor Questionnaire. Kerala Medical Journal 2009; 9(2): 59-67.

7. Saipanish R. Stress among medical students in a Thai medical school. Med teach 2003; 25: 502-6.

8. Sherina MS, Rampal L, Kaneson N. Psychological stress among undergraduate medical students. Med J Malasia. 2004, 59: 207-11

9. Shah M, HasanS, Malik S, Sreeramareddy CT. Perceived stress, sources and severity of stress among medical undergraduates in a Pakistani Medical School. BMC Medical Education. 2010; 10:2.

10. Buysse DJ, Reynolds III CF, Monk TH, Berman SR and Kupfer DJ (1989). The Pittsburgh Sleep Quality Index: A new instrument for Psychiatric practice and research. Journal of Psychiatric Resarch 28(2), 193-213.

11. Giri P, Baviskar M, Phalke D. study of sleep habits and sleep problems among medical students of Pravara institute of medical sciences Loni, Western Maharashtra, India. Ann med Health Sci Res. 2013; 3: 51-54.
12. Cohen S, Kamarck T, Mermelstein R. A global measure of perceived stress. J Health Socbehav. 1983; 24: 385-96

13. Feng GS, Chen JW, Yang XZ. Study on the status and quality of sleep-related influencing factors in medical college students. Zhonghua Liu Xing Bing XueZaZhi. 2005; 26: 328 - 331.

14. Pilcher JJ, Ginter DR, Sadowsky B. sleep quality versus sleep quantity: relationship between sleep and measures of health, wellbeing and sleepiness in college students. J Psychosom.Res. 1997; 42: 513-4

15. Jean Louis G, Von Gizycky H, Zifi F, Nunes J. mood states and sleepiness in college students:- influence of age, sex, habitual sleep and substance use. Percet Mot Skills. 1998; 87: 507-12. 